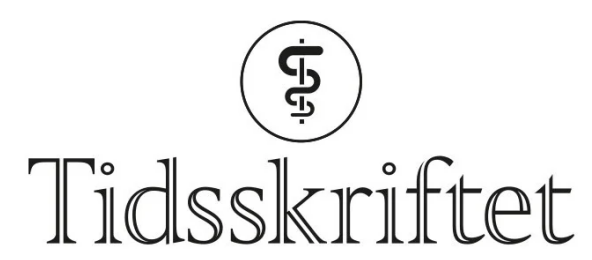

DEN NORSKE LEGEFORENING

\title{
Torstein Lyberg
}

\author{
MINNEORD \\ PER SKJELBRED \\ HANS ERIK HØGEVOLD \\ PÅL GALTELAND \\ OLAV ANDERS OLSTAD
}

HARALD ARNESEN

PETER KIERULF

TRUDE ASPELIN

ROLF HANOA

TOR P. UTHEIM

Torstein døde på Diakonhjemmet Sykehus 12. oktober, 74 år gammel, etter lengre tids sykdom. Med han er en av bautaene i norsk maxillofacial kirurgi og forskning gått bort. Torstein var tannlege, lege, dr.med. og spesialist i maxillofacial kirurgi.

Han ble i 1984 avdelingsoverlege ved Kjeve- og ansiktskirurgisk avdeling, Ullevål sykehus. Her innførte han en rekke nye behandlingsmetoder som i løpet av få år brakte avdelingen opp på et høyt faglig nivå. Brudd i ansiktsskjelettet ble behandlet med moderne plateosteosyntese, og ansiktsdefekter ble rekonstruert med mikrovaskulære transplantater og vevsekspansjonsteknikker, lenge før slike teknikker ble brukt i plastikkirurgi eller andre spesialiteter i Norge. Han startet samarbeid med øyeavdelingen om orbita- og okuloplastikkirurgi. Torstein innførte også moderne kraniofacial kirurgi i Norge, utført på Ullevål sykehus. Tidligere ble disse pasientene sendt til utlandet. 
Allerede som tannlegestudent fattet han interesse for basalforskning. Han ble inspirert og veiledet av professor Jon Jonsen ved Odontologisk institutt for mikrobiologi og ble stipendiat mens han studerte medisin. Han samarbeidet med blant annet Hans Prydz og andre fremtredende navn i norsk cellebiologi- og koagulasjonsforskning. Han disputerte på et arbeid om tromboplastin i 1984. Ved siden av klinisk aktivitet som avdelingsoverlege fortsatte han med forskning. I 199o ble Forskningsforum Ullevål sykehus opprettet, og Torstein ble leder for seksjonen Cellebiologi og metabolisme. På grunn av helseplager valgte han å trappe ned i den kliniske stillingen og ble i 1992 ansatt som heltidsforsker i Forskningsforum. Her var han en sentral tilrettelegger av avansert forskning med internasjonale forgreninger. Med sine store kunnskaper, ro og vennlighet var han en svært godt likt leder av forskningsgruppen. Han veiledet mange til doktorgrad og publiserte nærmere 300 artikler. I 1992 mottok han Ullevåls pris for fremragende forskning.

Torstein var innovatør, dyktig kirurg og forsker som var genuint opptatt av vitenskap og fag. Han var en rolig og stillferdig person som ikke likte for mye oppmerksomhet. En rekke ganger ble han tilbudt professorater, men takket alltid nei, da han mente det var forbundet med plikter han ikke var villig til å bruke tid på.

I 2013 døde hans kjære kone Eva. Samtidig ble han diagnostisert med en alvorlig sykdom. Selv om de siste årene var preget av sykehusbehandling og sviktende helse, fortsatte han med forskningen nesten helt til det siste.

Våre tanker går til hans datter Ingvild og resten av familien.

Publisert: 8. november 2021. Tidsskr Nor Legeforen. DOI:10.4045/tidsskr.21.0736

(C) Tidsskrift for Den norske legeforening 2023. Lastet ned fra tidsskriftet.no 26. april 2023. 